\title{
CURRENT DISTRIBUTION OF Achatina fulica, IN THE STATE OF SÃO PAULO INCLUDING RECORDS OF Aelurostrongylus abstrusus (NEMATODA) LARVAE INFESTATION
}

\author{
Fernanda Pires OHLWEILER(1), Marisa Cristina de Almeida GUIMARÃES(1), Fernanda Yoshika TAKAHASHI(1) \& Juliana Manas EDUARDO(1)
}

\begin{abstract}
SUMMARY
The currently known distribution range of Achatina fulica Bowdich, 1822, in the state of São Paulo, Brazil, is presented. The record of A. fulica naturally infested with Aelurostrongylus abstrusus larvae (Railliet, 1898) (Nematoda: Metastrongylidae) can be found in the city of Guaratinguetá. It was found A. fulica with Metastrongylidae larvae without known medical and veterinary importance in the cities of Carapicuíba, Embu-Guaçu, Itapevi, São Caetano do Sul, São Paulo and Taboão da Serra.
\end{abstract}

KEYWORDS: Achatina fulica; Geographical distribution; São Paulo; Aelurostrongylus abstrusus

\section{INTRODUCTION}

Achatina fulica Bowdich, 1822 is an African terrestrial mollusk, registered in Africa, Southeast Asia, Pacific Islands, Australia and Japan, and it was introduced in the American continent around 1939 ${ }^{14,19}$. In Brazil, the species was introduced in the state of Paraná in the 80's, for commercial use, and later spread to other Brazilian states ${ }^{10}$. Currently the species can be found in all Brazilian states, except Acre, Roraima and Amapá ${ }^{11,15}$.

A while ago, A. fulica was restricted to antropic environments, but due to the saturation of these areas the species invaded regions of native forests ${ }^{6}$. Nowadays, A. fulica can be found in forests, scrubs, "caatinga", swamp, vegetable-gardens, agriculture, plantations, strips of land, yards and gardens $s^{4,17}$. It can be found in soil, arbor, in decomposing material and dumps ${ }^{6,13,19}$.

The deposition of common solid residue in the urban environment is a factor that favors the maintenance and proliferation of the species, therefore increases the availability of food and shelter for specimens ${ }^{5,12}$.

Because of their voracious feeding habits, with some recorded cases of cannibalism, the species contributes to the extermination of native fauna, diminishing the amount of available resources and competing for physical space. These factors, including the absence of natural pathogens, render $A$. fulica a high capacity for dispersion, causing serious disequilibrium and loss of biodiversity ${ }^{9,17}$.

The species present great epidemiological interest, for it acts as an intermediate host for the Angiostrongylus cantonensis (Chen, 1935) nematodes, which causes eosinophilic meningoencephalitis in Africa,
Asia and Oceania ${ }^{12,16}$ and also for Angiostrongylus costaricensis Morera \& Céspedes, 1971, which causes abdominal angiostrongyliasis, from southern USA to northern Argentina ${ }^{15}$.

In light of the great concern generated by A. fulica, the aim of this work was to determine the current geographical distribution of this species in the state of São Paulo, in addition to recording those infected by the larvae of Aelurostrongylus abstrusus (Railliet, 1898) (Nematoda: Metastrongylidae) in the city of Guaratinguetá.

\section{MATERIAL AND METHODS}

The distribution record for A. fulica, in the state of São Paulo, was compiled from the available bibliography, data from the Malacology Laboratory of SUCEN and the scientific collection of the Zoology Museum of the University of São Paulo (MZSP).

The technique of artificial digestion with Pepsin was used in order to examine specimens of $A$. fulica from the city of Carapicuíba (collected by DPE team, in November and December of 2009; source: Paraná Street - S2332'8.3" x O4649'46.3”; 35 specimens and Coração de Jesus Street - S2331'23.4" x O4650'52.9”; six specimens), EmbuGuaçu (led by the Zoonoses Control Center of the county to the DPE malacology laboratory, in November and December of 2009; source: Francisco Munhoz Cegarra Street, Jardim Boa Vista District S2350'23.6" x O4649'11.2"; 44 specimens and Firmino Alves Filho Street - S2350'22.6” x O4649'6.4”; 41 specimens), Guaratinguetá (103 specimens; collected by DPE team, in March and April of 2008; source: Olinda, Bairro Vista Alegre Street), Itapevi (three specimens; led by the Zoonoses Control Center of the county to the DPE lab, in

Financial Support: FAPESP (No 2006/56217-4, Nº 2008/57792-8)

(1) Laboratório de Malacologia, Superintendência de Controle de Endemias (SUCEN), São Paulo, SP, Brasil.

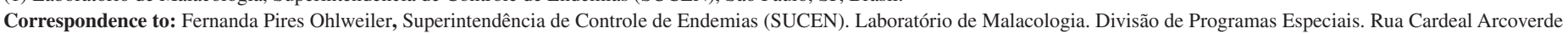
2878. Pinheiros. 05408-003 São Paulo, SP, Brasil. E-mail: fernandap@ sucen.sp.gov.br 


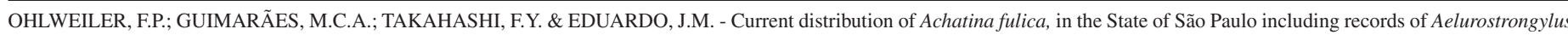
abstrusus (Nematoda) larvae infestation. Rev. Inst. Med. Trop. Sao Paulo, 52(4): 211-4, 2010.

February of 2010; source: Cajamangas Street, Jardim Vitápolis District), São Caetano do Sul (13 specimens; led by Zoonoses Control Center of the county to the DPE lab, in December of 2009; source: Aurélia Street, Olímpico District - S2337'2.4” x O46³3'24.0”) and Taboão da Serra (two specimens; led by the Zoonoses Control Center of the county to the DPE lab, in March of 2010; source: Agueda Gonçalves Street, Jardim Pedro Gonçalves District - S2336'49.4” x O4646’24.6”), SP.

Only the foot of the specimens was used in the artificial digestion process, the remainder of the body was discarded. The material was macerated and placed in Petri dishes together with the digestive fluid along with Pepsin Lot Sigma 123K0661 for two hours in a water bath under $37^{\circ} \mathrm{C}$ for the digestion process. The amount of digestive fluid was enough to cover the material. Afterwards, the product of the digestion was transferred to the Baermann funnel, where it remained for two hours. The filtered material was then examined under LEICA MZ95 stereoscopic microscope and LEICA DFC 420 light microscope. Images were taken from the light microscope using LEICA QWIN Image Processing and Analysis Software, and from the Confocal Laser Scanning Microscope, LSM 510 Meta-Zeiss. The confocal microscope belongs to the Parasitology Laboratory of the Butantã Institute, São Paulo.

\section{RESULTS AND DISCUSSION}

The Brazilian states mostly infested by A. fulica are Goiás, São Paulo, Paraná, Rio de Janeiro, Mato Grosso, Espírito Santo, and Minas Gerais ${ }^{17}$. In the state of São Paulo, the geographical distribution of A. fulica is widened from 69 counties $^{17}$ to 105 . In São Paulo, the species was recorded in the cities of Aparecida, Arapeí, Areias, Atibaia, Americana, Bananal, Bom Jesus dos Perdões, Botucatu, Bragança Paulista, Caçapava, Cachoeira Paulista, Campinas, Caraguatatuba, Cruzeiro, Cunha, Guarujá, Ilhabela, Igaratá, Iporanga, Itanhaém, Itariri, Jacareí, Jacupiranga, Jambeiro, Jarinu, Jundiaí, Lagoinha, Lavrinhas, Lençóis Paulista, Limeira, Lorena, Mairiporã, Mongaguá, Monteiro Lobato, Natividade da Serra, Nazaré Paulista, Panorama, Paraibuna, Paulínia, Paulicéia, Pedreiras, Peruíbe, Pindamonhangaba, Piracaia, Piracicaba, Potim, Praia Grande, Presidente Prudente, Queluz, Redenção da Serra, Registro, Rio Claro, Ribeirão Preto, Roseira, Santa Branca, Santos, Santo André, Santo Antonio do Pinhal, São Bento do Sapucaí, São José do Barreiro, São José dos Campos, São Luiz do Paraitinga, São Sebastião, São Paulo, São Vicente, Silveiras, Sorocaba, Sumaré, Tietê, Taubaté, Tremembé, Ubatuba and Votuporanga ${ }^{3,4,14}$.

Based on the data from the Malacology Laboratory of SUCEN and from MZUSP, the distribution of A. fulica, in the state of São Paulo is extended to Águas de Lindóia, Amparo, Avaré, Barra Bonita, Bertioga, Boqueirão, Cajamar, Carapicuíba, Cotia, Embu-Guaçu, Estiva Gerbi, Ferraz de Vasconcelos, Guaratinguetá, Guararema, Guarulhos, Iguape, Itapeva, Itapevi, Itapira, Mogi-Mirim, Pilar do Sul, Pirapora do Bom Jesus, Pirassununga, Ribeirão Pires, Santa Isabel, Santana do Parnaíba, São Caetano do Sul, São José do Rio Pardo, Taboão da Serra, Valinhos, Vargem Grande do Sul and Vargem Grande Paulista.

A. fulica has been found in Brazil (Espírito Santo and São Paulo), infested by larvae of Metastrongyloidea A. cantonensis $^{1,2}$. In the state of Santa Catarina (City of Florianópolis), 244 specimens of A. fulica were collected, which were imposed to experimental infection by $A$. costaricensis larvae ${ }^{8}$. Among these specimens, one (prevalence of $0.4 \%$ ) has demonstrated itself susceptible to the parasite. NEUHAUSS et al. ${ }^{8}$ believe in the possibility of $A$. costaricensis transmission by A. fulica, which nowadays is considered the potential host of the parasite in Brazil. FRANCO-ACUÑA et al. ${ }^{7}$ record A. fulica infested by larvae of nematodes in the state of Rio de Janeiro (City of Mesquita).

Recently, specimens of A. fulica from the city of Guaratinguetá, were found infested by larvae (in the period of larval transition L2 for L3; moulting larvae) of Metastrongyloidea A. abstrusus (Figs. 1-3). A.
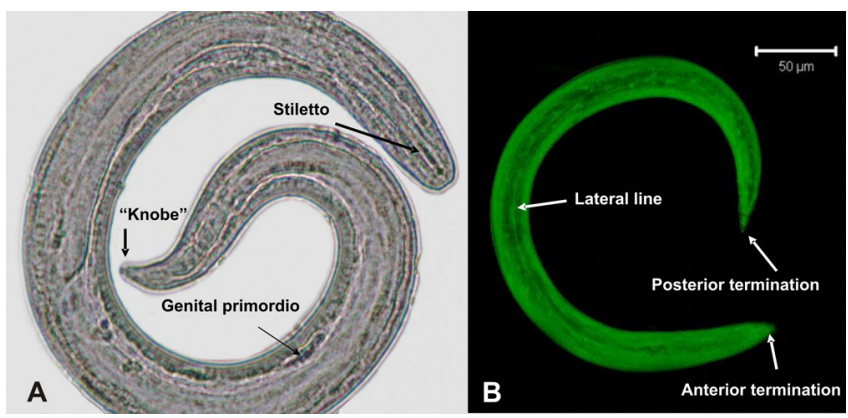

Fig. 1 - Aelurostrongylus abstrusus (Railliet, 1898). A-B: Larvae. A: Light microscope, 920 X. B: Confocal Laser Scanning Microscope.

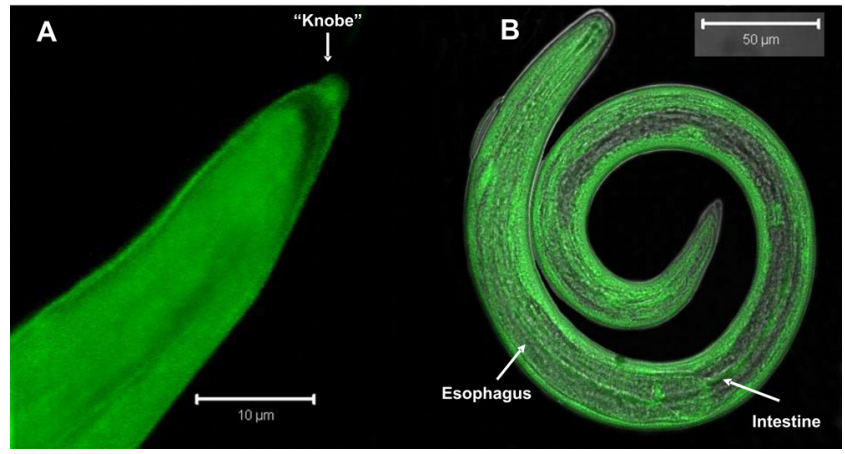

Fig. 2 - Aelurostrongylus abstrusus (Railliet, 1898). A: Detail of the posterior region of the larvae in the period of larval transition L2 for L3. B: larvae in the period of larval transition L2 for L3. Confocal Laser Scanning Microscope.

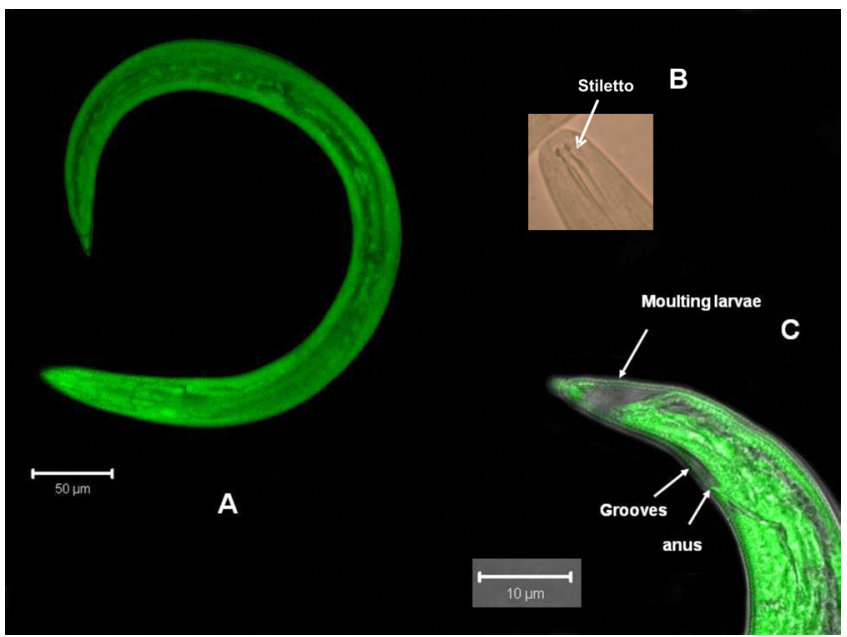

Fig. 3 - Aelurostrongylus abstrusus (Railliet, 1898). A: Larvae in the period of larval transition L2 for L3. B: Detail of the anterior region of the larvae. C: Detail of the posterior region of the larvae. A,C: Confocal Laser Scanning Microscope. B: Light microscope. 
OHLWEILER, F.P.; GUIMARÃES, M.C.A.; TAKAHASHI, F.Y. \& EDUARDO, J.M. - Current distribution of Achatina fulica, in the State of São Paulo including records of Aelurostrongylus abstrusus (Nematoda) larvae infestation. Rev. Inst. Med. Trop. Sao Paulo, 52(4): 211-4, 2010.

Table 1

Measurements ( $\mu \mathrm{m})$ of Aelurostrongylus abstrusus (in the period of larval transition L2 for L3)

\begin{tabular}{|c|c|c|c|}
\hline Measurements & Mean & Interval & Specimens \\
\hline Length & 424.5 & $355.18-516.30$ & 6 \\
\hline Width at the base of esophagus & 26.1 & $24.38-27.16$ & 6 \\
\hline Stiletto (length) & 20.59 & $18.5-23.44$ & 6 \\
\hline Esophagus (length) & 210 & $202.84-223.19$ & 4 \\
\hline Distance from the genital primordium up to the posterior region & 141 & $134.83-146.11$ & 3 \\
\hline Distance from the excretory pore up to the anterior region & 82.8 & $72.11-88.37$ & 3 \\
\hline Distance from the anus up to the posterior region & 31 & $25.28-37.85$ & 5 \\
\hline Posterior termination & 2.87 & $2.69-3.55$ & 7 \\
\hline
\end{tabular}

abstrusus is a Nematoda Metastrongyloidea, parasite of domestic dogs and cats, primates and badgers. The definite host becomes infected while ingesting mollusks infested with the parasite. In Brazil, the A. abstrusus has usually been found in the lungs of domestic cats ${ }^{18}$.

A. abstrusus infesting A. fulica had been mentioned by THIENGO et $a l .{ }^{18}$ in the states of Espírito Santo (two cities), Goiás (five cities), Mato Grosso (one city), Minas Gerais (one city), Rio de Janeiro (four cities), São Paulo (one county) and Sergipe (one city). In São Paulo, the authors recorded A. fulica infested with nematodes only in the city of Jundiaí.

A. fulica from the cities of Carapicuíba, Embú-Guaçu, Itapevi, São Caetano do Sul and Taboão da Serra had been discovered infested by larvae of Metastrongyloidea, without medical and veterinary importance known until that moment.

The identification of the larvae was based on morphological characteristics, such as the presence of a lateral line throughout the body, grooves in the tegument, position of genital and excretory pores and the presence of stiletto in the anterior extremity and a structure similar to a rounded button ("knobed") in the posterior extremity.

The measurements of A. abstrusus larvae (in the period of larval transition L2 for L3) are presented on Table 1.

The presence of A. fulica in our territory is considered extremely alarming not only due to the damages caused to agriculture and for their contribution to the extermination of our native malacofauna, but also due to the fact that it is a host mollusk for nematodes of medical and veterinary importance. This study shows that there is a need to establish an epidemiological monitoring system in order to prevent the possible installation of parasitical points where these mollusks are present.

\section{RESUMO}

\section{Distribuição atual de Achatina fulica Bowdich, 1822 no Estado de São Paulo com registro de infestação por larvas de Aelurostrongylus abstrusus (Nematoda)}

É apresentada a distribuição de Achatina fulica Bowdich, 1822 no Estado de São Paulo, Brasil. É fornecido o registro de A. fulica naturalmente infestada por larvas de Aelurostrongylus abstrusus (Railliet, 1898) (Nematoda: Metastrongylidae) no município de Guaratinguetá. Foi encontrada A. fulica portando larvas de Metastrongylidae sem importância médica e veterinária conhecida nos municípios de Carapicuíba, Embu Guaçu, Itapevi, São Caetano do Sul, São Paulo e Taboão da Serra.

\section{REFERENCES}

1. Caldeira RL, Mendonça CLGF, Oliveira CG, Graeff-Teixeira C, Lima WS, Carvalho OS. Moluscos terrestres naturalmente infectados por Angiostrongylus cantonensis no Brasil. In: Resumos do XX EBRAM, Rio de Janeiro; 2007. p. 369

2. Caldeira RL, Mendonça CLGF, Goveia CO, Lenzi HL, Graeff-Teixeira C, Lima WS, et al. First record of molluscs naturally infected with Angiostrongylus cantonensis (Chen, 1935) (Nematoda: Metastrongylidae) in Brazil. Mem Inst Oswaldo Cruz. 2007;102:887-9.

3. Carvalho OS, Teles HMS, Mota EM, Mendonça CLGF, Lenzi HL. Potentiality of Achatina fulica Bowdich, 1822 (Mollusca: Gastropoda) as intermediate host of the Angiostrongylus costaricensis Morera \& Céspedes 1971. Rev Soc Bras Med Trop. 2003;36:743-5.

4. Eston MR, Menezes GV, Antunes AZ, Santos ASR, Santos AMR. Espécie invasora em unidade de conservação: Achatina fulica (Bowdich, 1822) no Parque Estadual Carlos Botelho, Sete Barras, SP. Brasil (Nota Científica). Rev Inst Flor. 2006;18:173-9.

5. Fisher ML, Costa LCM, Kosloski MA, Beato KT, Fernandez AC, Colley E. Achatina fulica Bowdich, 1922 (Mollusca, Achatinidae): preferência e consumo de resíduos sólidos orgânicos produzidos em ambientes antrópicos. In: XVIII Encontro Brasileiro de Malacologia, 2003. Rio de Janeiro: UERJ; 2003. p. 241.

6. Fisher ML, Simião M, Colley E, Zenni RD, Silva DAT, Latoski N. O caramujo exótico invasor na vegetação nativa em Morretes, PR: diagnóstico da população de Achatina fulica Bowdich, 1822 em um fragmento de floresta ombrófila densa aluvial. Biota Neotrop. 2006;6(2):1-5.

7. Franco-Acuña DO, Pinheiro J, Torres EJL, Lanfredi RM, Brandolini SV. Nematode cysts and larvae found in Achatina fulica Bowdich, 1822. J Invertebr Pathol. 2009;100:106-10.

8. Neuhauss E, Fitarelli M, Romanzini J, Graeff-Teixeira, C. Low susceptibility of Achatina fulica from Brazil to infection with Angiostrongylus costaricensis and A. cantonensis. Mem Inst Oswaldo Cruz. 2007;102:49-52.

9. Raut SK, Barker G. Achatina fulica Bowdich and other Achatinidae pest in tropical agriculture. In: Barker GM, editor. Molluscs as croup pest. Wallingford: CABI; 2002. p. $55-144$ 
OHLWEILER, F.P.; GUIMARÃES, M.C.A.; TAKAHASHI, F.Y. \& EDUARDO, J.M. - Current distribution of Achatina fulica, in the State of São Paulo including records of Aelurostrongylus abstrusus (Nematoda) larvae infestation. Rev. Inst. Med. Trop. Sao Paulo, 52(4): 211-4, 2010.

10. Silva M. Informe Técnico. Achatina fulica Bowdich, 1822 (Caramujo gigante africano). Rio de Janeiro: Secretaria de Estado de Saúde, Subsecretaria de Assistência à Saúde, Centro de Vigilância Epidemiológica, Coordenação de Vigilância Ambiental em Saúde; 2003.

11. Silva PS, Oliveira JL, Santos SB. Achatina fulica Bowdich, 1822 no Brasil: revisão bibliográfica. In: Livro de Resumos do XX EBRAM, 2007. Rio de Janeiro, 2007. p. 229.

12. Simião MS, Fisher ML. Estimativa e inferência do método de controle do molusco exótico Achatina fulica Bowdich 1822 (Stylommatophora: Achatinidae) em Pontal do Paraná, litoral do estado do Paraná. Cad Biodivers. 2004;4(2):74-83.

13. Simone LR. Gastropoda terrestres. Mollusca terrestres. In: Joly CA, Bicudo $\mathrm{CE}$, organizadores. Biodiversidade do Estado de São Paulo, Brasil: síntese do conhecimento ao final do Século XX. 5: Invertebrados terrestres. São Paulo: FAPESP; 1999. p. 1-8.

14. Teles HMS, Vaz JF, Fontes LR, Domingos MF. Registro de Achatina fulica Bowdich, 1822 (Mollusca, Gastropoda) no Brasil: caramujo hospedeiro intermediário da angiostrongilíase. Rev Saúde Pública. 1997;31:310-12.
15. Thiengo SC, Fernandez MA. Achatina fulica in Brasil: the current situation. Tentacle. 2005;13:7.

16. Thiengo SC, Fernandez MA. Informe técnico: Achatina fulica Bowdich, 1822 (Caramujo gigante africano). Rio de Janeiro: Secretaria de Estado de Saúde, Subsecretaria de Assistência à Saúde, Centro de Vigilância Epidemiológica, Coordenação de Vigilância Ambiental em Saúde, Instituto Oswaldo Cruz; 2005.

17. Thiengo SC, Faraco FA, Salgado NC, Cowie RH, Fernandez MA. Rapid spread of an invasive snail in South America: the gigant African snail, Achatina fulica, in Brazil. Biol Invasions. 2007;9:693-702.

18. Thiengo SC, Fernandez MA, Torres EJ, Coelho PM, Lanfredi RM. First record of a nematode Metastrongyloidea (Aelurostrongylus abstrusus larvae) in Achatina (Lissachatina) fulica (Mollusca, Achatinidae) in Brazil. J Invertebr Pathol. 2008;98:34-9.

19. Vasconcellos MC, Pile E. Ocorrência de Achatina fulica no Vale do Paraíba, Estado do Rio de Janeiro, Brasil. Rev Saúde Pública. 2001;35:582-4.

Received: 11 November 2009

Accepted: 25 May 2010 